\title{
The suitcase, the samurai sword and the Pumpkin: Asian crime and NZ news media treatment
}

\section{ABSIIRACI}

In 2005 and 2007, two high profile crimes were reported in the New Zealand media. The first case involved the murder of a young Chinese student, Wan Biao, whose dismembered body was discovered in a suitcase. The second case involved domestic violence in which a Chinese man murdered his wife and fled the scene with their young daughter-who the press later dubbed 'Pumpkin' when she was found abandoned in Melbourne, Australia. The authors discuss how news and current affairs programmes decontextualise 'Asian' stories to portray a clear divide between the 'New Zealand' public and the separate 'Asian other'. Asians are portrayed as a homogenous group and the media fails to distinguish between Asians as victims of crimes as a separate category to Asians as perpetrators of crimes. This may have consequences for the New Zealand Asian communities and the wider New Zealand society as a whole.

Keywords: current affairs, media, diversity, Asian crime, ethnic representation, television news

\section{SARAH BAKER and S. JEANIE BENSON}

AUT University, Auckland

\section{Introduction}

TN APRIL 2005, Wan Biao a young Chinese international student was found dead, his body disposed of in a suitcase floating in the Waitemata Harbour, Auckland, New Zealand. This case involved the kidnapping and torture of a Chinese international student. The perpetrators were fellow Chinese international students apparently motivated by ransom. A second high profile murder of a Chinese woman was reported in October 2007. The victim, An An Liu an immigrant allegedly murdered by Nai Yin Xue her 
husband. In this crime her body was later found in the boot of her car. ${ }^{1}$ News and current affairs broke with the story of the abandoned unnamed girl who was nicknamed by police and later the media as 'Pumpkin'. The story used CCTV footage of the girl shown abandoned in Melbourne train station while an unnamed man who was later identified as her father Nai Yin Xue, fled to the USA. At this point, the murderers of Wan Biao have been sentenced and in the Pumpkin case, the coverage on America's Most Wanted (AMW, 2008), led to Nai Yin Xue's capture and return to New Zealand where he faces trial.

Each story is different, yet offers an opportunity to explore the treatment Asian social groups receive from New Zealand news media as either victims or perpetrators of violent crimes. In previous research on Asian representation, Benson $(2003,2004)$ found that coverage of Asian people is frequently presented in crime stories and that 'Asian' becomes a category whereby many ethnicities are conflated for the ease of journalists and possibly audiences (Munshi, 1998; Spoonley \& Trlin, 2003).

This article analyses how news and current affairs frames both stories. The analysis of the coverage of Wan Biao, demonstrates that television news and current affairs refuses to portray the young man as a victim. The analysis of the Pumpkin or An An Liu story demonstrates how the death of the mother is forgotten in the hype and focus on the abandoned child. As such, important cultural information and references are lost, and there are more questions raised than answers provided by either news or current affairs. Building on previous media research into news and current affairs programmes, this article incorporates themes on Asian identity and seeks to analyse how these two contemporary stories fail the community they are reporting on and the New Zealand audience at large.

\section{Background}

Previous criticism of New Zealand news and current affairs has focused on the examinations of the impact of deregulation on broadcasting. These criticisms suggest in a deregulated media environment programme quality has been affected by the promotion of ratings and profits over other considerations. Examinations into news on state broadcaster Television One (TV1) by Atkinson (1994) and subsequent studies by Comrie (1996) and Cook (2000) suggest that news and current 
affairs have become depoliticised, morselised and tabloidised. ${ }^{2}$ Other critics have sugested that the commercialised environment has had dramatic impacts on programme quality (Cocker, 2006; Edwards, 2002; Hope, 2000, Kelsey, 1995; Saunders, 2004; Thompson, 2004). A common finding has been the reduction of political coverage to the expense of a focus on celebrity, human interest and crime stories. Baker (2007) notes that on Agenda, a serious charter current affairs programme, that politics was the main subject matter. ${ }^{3}$ In contrast, Television New Zealand's (TVNZ) week-nightly current affairs programme Close- $U p$, predominantly focused on entertainment, crime and human interest items (Ibid). Atkinson (2006) describes Campbell Live, the Television Three (TV3) week-nightly current affairs show, as more of an imitation of serious news journalism than serious current affairs. Atkinson (2006, p. 6) says:

But the drive to build audiences for advertisers places a premium on
news coverage of topics of interest to more affluent audiences, and
blunts journalism's critical edge. By catering to the popular taste for
entertainment, commercial media outlets restrict themselves to telling
audiences what they already know, or even worse, cultivating anti-social
habits of mind. News and current affairs audiences are urged to treat
social problems as non-systemic.

News and current affairs have been broadly criticised for perceived inadequacies which includes a reduction in information required to address issues, political events or decisions regarding civil society. However, little research has been carried out in New Zealand to examine how the commercialised base of broadcasting could be affecting the representations of ethnic minorities.

TVNZ has since 2003 had a charter where one aim is to broadcast quality news and current affairs programmes. However, advertising revenues and ratings continue to operate as primary objectives and measures of success. In this context, the accurate representation of ethnic minority groups is subordinated to the other considerations such as ratings. The representation of ethnic minorities is further problemitised by sensationalism that is characteristic of media representation of crime. This article follows previous international literature on studies into racism in the media. Allan (2004) for example, suggests news media representation of race in 'Western' countries in repeated studies is 
recurrently framed within the boundaries of dominant white cultural attitudes.

The examination of racial representation is exacerbated when combined with the topic of crime and it can be argued that fundamental problems are encountered when incorporating Chinese ethnic groups as victims of crime in the news media. Instances where media coverage moves beyond 'blood, bullets and soundbites' are few and far between (Allan, 2004, p. 143). Many studies suggest that news reporting focused on race-related issues is more likely to be sensational and superficial as it is politically dangerous and that this is even evident at the quality end of the news spectrum (Ibid). This prejudice frequently evident in media is at odds with notions of journalistic professionalism let alone impartial or socially responsible reporting.

The news media representation of Chinese and other Asian groups shows a marked tendency to promote these groups as perpetrators of particular crimes such as corruption and gambling as well as violent crimes (Benson, 2003 ; 2006). These ideas it could be argued stem from the early association of independent gambling houses that the Chinese goldmining sojourners were forced to create as they were banned from colonial drinking venues (Grant, 2002). It could be tempting to ascribe this process to simple stereotyping which is an accessible concept of cross-cultural relationships. Stereotypes are created in order to provide stepping stones or limited concepts to explain a relatively unknown culture (Bennett, 2005). But this line of reasoning cannot satisfactorily account for the lengthy struggle for representation that Chinese and other ethnic minorities have had to undergo in their struggle for media representation in New Zealand.

In essence, the media trend toward Asianisation provides a more reliable guide than simple stereotyping (Munshi, 1998). In this process, the various boundaries of ethnicity, culture and nationality are collapsed to re-assign an artificial regional identity of 'Asian' (Mathews, 2000). Asianisation is effected across occupation and residency as well and this means that East and South East Asian immigrants and international students are conflated with Chinese New Zealanders that have been established in New Zealand for many generations (Bennett, 1998). As a whole, Asian ethnic groups have climbed steadily from 6 percent in the 2002 census to 9.2 percent in 2006-but in Auckland, Asian totals have now reached 18.9 percent (StatisticsNZ, 2006). ${ }^{4}$ The ability to deal with the changing demographics of New Zealand is therefore important for media representation.

186 PACIFIC JOURNALISM REVIEW 14 (2) 2008 


\section{Methodology}

In order to analyse the framing and representation these two cases were examined through a reading of the accessible news media that was promoted on the free to air channels - TV1 and TV3. This preliminary case study uses a close-reading approach and qualitative analysis. Material is selected from clips from the TVNZ and TV3 websites and for the news samples a snowball type method was utilised, allowing the hyperlinks to perform as maps to lead to the next news output. In contrast, the current affairs coverage during this time was more limited so that each of the stories was included during the time period from April 2005 until March 2008.

Overall a sample of 24 news bulletins was collected on the Wan Biao case and a further 36 on the An An Liu case. Qualitative methods were used and analysis was conducted in two parts. The first was by tracking the chronology of events and stories. From these, a secondary thematic analysis was conducted in which the main themes of both cases were identified and analysed. The aim of this study is to examine the way stories unfold and how messages are conveyed to the New Zealand mainstream audience. This second aim is to uncover media discourses reinforced by the prevailing social discourses in New Zealand mainstream audiences. Finally, the impact of framing on story coverage is examined. 'By framing social and political issues in specific ways, news organisations declare the underlying causes and likely consequences of a problem and establish criteria for evaluating potential remedies of the problem' (T.E Nelson, Clawson, and Oxley 1997, as cited in Johnson-Cartee, 2005 , p. 26). Framing, it can be argued, affects the ultimate understanding of an issue.

\section{Findings}

More news coverage was collected from the TV3 site than from the TVNZ site. Equal size or content was not necessary as the delivery of TVNZ and TV3 are not specifically compared. Principally, the Wan Biao story was characterised by the continual usage of the phrase 'Suitcase Murder'. Effectively, this phrase depersonalises Wan Biao as victim and centralises the image of an anonymous suitcase. Recurring visual images of the battered black suitcase are presented against a white backdrop throughout the various news and current affairs representation. The dominance of the suitcase asserted over the identity of Wan Biao as the victim, is enhanced by the 
TVNZ 'More testimony in suitcase trial' (4th September, 2007) which headlines the news story by likening Wan Biao's body to a mannequin. This is a paraphrase of Andrew Willamott's testimony (the recreational boater who discovered Wan Biao), who said: 'I suspected it may have been a mannequin'.

More impersonal images follow in the news bulletin 'Body in suitcase accused appear' on 5 September 2007, and include the hotel window in the footage and the sign 88 Cook St, the address of the apartment Wan Biao lived in alongside the accused Chinese international students. Unlike the other contextual shots, which are ambiguous, this one shot shows where they lived. The apartments appear grey, lifeless and uninviting which echoes the repetitive images of the suitcase and Wan Biao's photograph. This association is compounded in the TVNZ story 'Disturbing revelation in suitcase trial' on 14 September 2007, and this effect continues with the description of the witnesses. Similar to the three accused, a witness's name is not supplied, either by repetition or with subtitles. Although this effect is slightly mitigated by referring to Lianda Yin as Mr Yin, there is still a barrier to comprehending or remembering his full name. Close relationships shared by the accused and Wan Biao evoke an image closer to a 'den of iniquity' rather than a normal apartment shared by students.

Once the guilt of the perpetrators is legally ascertained, the police spokesperson is the official face of the police represented in TV3 news in "Body in a suitcase" murderers sentenced to a life in prison' (6 December 2007). Full footage of the press conference is included and his name and rank are clearly represented in order to underscore his position as an expert in this situation. The framing of a legal judgement effectively provides a justification to banish any doubt an audience may have as to the guilt of the perpetrators and the level of violence they showed in this crime.

The most important omission in this footage is the lack of visual imagery and quotes from direct Chinese sources. The family are rarely represented, there is no comment from the Chinese Consulate, nor is there direct representation from the friends of Wan Biao. To some extent the language and cultural barriers represented by the Biao family contribute to this. But the reporters must be held accountable as there was little reference to these difficulties about the kinds of depth that this missing information would have brought to bear on the story. As noted earlier, it is entirely appropriate to grant Biao 
privacy, but the lack of reference to these missing components frames the story dispassionately.

This representation casts Wan Biao into the category of the 'other', where he is presented as an unfortunate and anonymous victim. By contrast, the crime is represented as gruesome and is suggestive of an epidemic of related Asian violence. Campbell Live attempts to examine the epidemic with 'Asian crime - scourge or media beat up' (28 April, 2006). It provides an investigation into this story and places this crime in context with other Chinese kidnappings in Auckland and around New Zealand. Interestingly, Campbell prefaces these stories with the statement 'And the fact is by ethnic groupings, Asian people are among the least criminal'. However, the meaning or impact of this statement is contradicted by high profile Asian crime that is supported by extensive footage from the TV3 archive. The view presented by Campbell Live is that these kidnappings do not just happen in the big urban centres like Auckland but also in smaller centres such as Hamilton. Indistinguishable from other Asian ethnic groups, Chinese kidnappings and an account of a Japanese Columbus College student are represented together. Asian international students are linked with deviance, corruption and violence as these crimes are often committed with the intention of raising illicit funds for the Asian perpetrators. This perspective is a familiar theme in media representations of Asian international students and has been noted in previous media research (Benson, 2006).

\section{An An Liu}

The case of the murder of An An Liu and the abandonment of her daughter Qian Xun Xue unfolds in 2007 and into 2008. The first story analysed: 'Interview with the officer in charge of the abandoned toddler case' comes from TV3 news on 17 September 2007. It tells of how a 'small girl' has been left at the railway station in Melbourne and the police believe that the family were visiting relatives. Qian Xun Xue was nick-named "Pmpkin" because she was wearing a pumpkin patch brand vest. Dubbing her Pumpkin after a well known New Zealand children's clothing brand signifies that both girl and clothing originate from New Zealand (Pumpkin Patch, n.d.). The story then explains that the police are trying to locate the girl's mother in New Zealand. Framing is evident in the emotional scene of an abandoned young girl that is heightened by CCTV footage showing her alone in the Melbourne train station. 
On the same day, TVNZ's 'Abandoned girl came from NZ' (17 September 2007) $6 \mathrm{pm}$ news coverage, takes a very similar though slightly more sombre examination of the story in comparison, with the main difference being that Little Pumpkin is referred to as the 'Wee girl'. Again, emotionally laden words inform the audience that the girl is very young and vulnerable. The Melbourne police officer in charge of the case is interviewed. The official authority representation is diluted by the focus on Qian Xun Xue described as eating vegemite and toast which has associations of both New Zealand and Australian cultural identity hallmarks, which offers the viewer an illusion of a 'mainstream' nationality without ethnic uniqueness.

This theme repeats itself in current affairs programme Close-Up 'Pumpkin', which covers this item on 18 September 2007. Similar to the news bulletins that preceded it, it is framed within a heightened emotionally laden framework. Qian Xun Xue is presented as 'Little Pumpkin' and there is more reference to her Pumpkin Patch brand clothing. Mark Sainsbury editorialises the story when he rhetorically asks the audience how 'any mother could abandon a small child' which is followed by the summary statement 'Any mother would be desperate'. Sainsbury's questions add drama to the report but little substance about the facts as they centre on the frequency of abandonment cases in general and the mood of the child. Other emotional and possibly irrelevant themes are introduced as the father, Nai Yin Xue's character is speculated on due to his successful evasion of authorities and his association with martial arts and as an owner of martial arts weapons. Interestingly, there is an error in reporting which indicates that his sword is a 'samurai' sword, but this is actually an incorrect term for a sword used in tai chi chuan practised by Nai Yin Xue. ${ }^{5}$

Two types of emotionality are heightened by this type of reporting, the distress over an abandoned New Zealand child which is followed by the association of fear of Nai Yin Xue who is an immigrant practising 'Asian' martial arts. Close Up describes its aims as providing 'high quality, reporterdriven, current affairs stories about New Zealanders and what matters to them' (TVNZ, 2007, para 4). Inaccuracies in terminology and conflation of ethnic identity in this case suggest that 'high quality' takes a lesser priority than graphic and emotional representation of a serious event.

The next story analysed from TV3 is from Tuesday, 18 September 2007, 'Pumpkin's father has another daughter who disappeared'. The thrust 
of the story is that police fear for the safety of An An Liu the mother and continue to refer to Qian Xun Xue as 'Little Pumpkin'. New background information is added by reference to a 'startling' documentary, which suggests that the father, Nai Yin Xue has an older daughter who has vanished. This is a dramatised interpretation of an amateur documentary by a UNITEC polytechnic student in Auckland who is interviewing his martial art instructor about his life. In this footage Nai Yin Xue, makes mention of some emotional regret about a dispute with an elder daughter. ${ }^{6}$ Yet a subsequent interview with the UNITEC tutor indicate that they do not believe that Nai Yin Xue's emotions regarding his elder daughter are 'real'. This conjecture is an attempt to construct a picture of the 'criminal' yet is hardly factual.

The third story from TV3 on 19 September, 'Police: Body found at Xue house', consists of the discovery of the body of An An Liu which has been found in the boot of her car which had been discovered upon its removal from the scene of investigation. Although primarily about An An Liu, there is a headline with 'Pumpkin's Plight' which links the An An Liu story around Qian Xun Xue. A voiceover introduces the theme of domestic violence by suggesting that 'a neighbour heard loud voices', which is then echoed by a shot of a neighbour saying that she 'heard loud voices'. At this point there is more footage of Nai Yin Xue claiming his 'samurai' sword from the Henderson police which is offset by the information that he taught tai chi chuan. As tai chi chuan is often practised for relaxation and without weapons (Zee, 2002), for the viewer, there is a conflation of 'Asian' cultural pastimes with violence.

Within this story, a number of pseudo experts are used to frame the story and review the major background issues. These include a Los Angeles police officer who is briefly interviewed but contributes very little, as well as the website manager from Sky Kiwi and a Horton Publishing representative. Political representation from Pansy Wong, National Party list MP for Auckland Central, and the Minister of Ethnic Affairs Chris Carter follow. The manager from Sky Kiwi suggests that Nai Yin Xue has conflicts with the ethnic Chinese community but this is a 'private matter', while the Horton publishing representative speculates that Nai Yin Xue appeared to be in debt. In contrast, Pansy Wong talks about the visa difficulties of An An Liu's mother, which is countered by Chris Carter offering 'assistance'. An audio file from An An Liu's mother and Qian Xin Xue's grandmother thanks the Australian 
authorities. Despite the diversity and importance of the experts, there seems to be little actual investigation into the reasons for An An Liu's murder. But this contrasts with the overwhelming interest Nai Yin Xue's personal circumstances. The politicians add weight to the situation, by rushing to assist the family with visas and frame this situation in the light of a national tragedy to save the toddler. This is reinforced by smiling images of the child throughout the television and print news media. For example, this is seen in the following Herald on Sunday article (Figure 1).

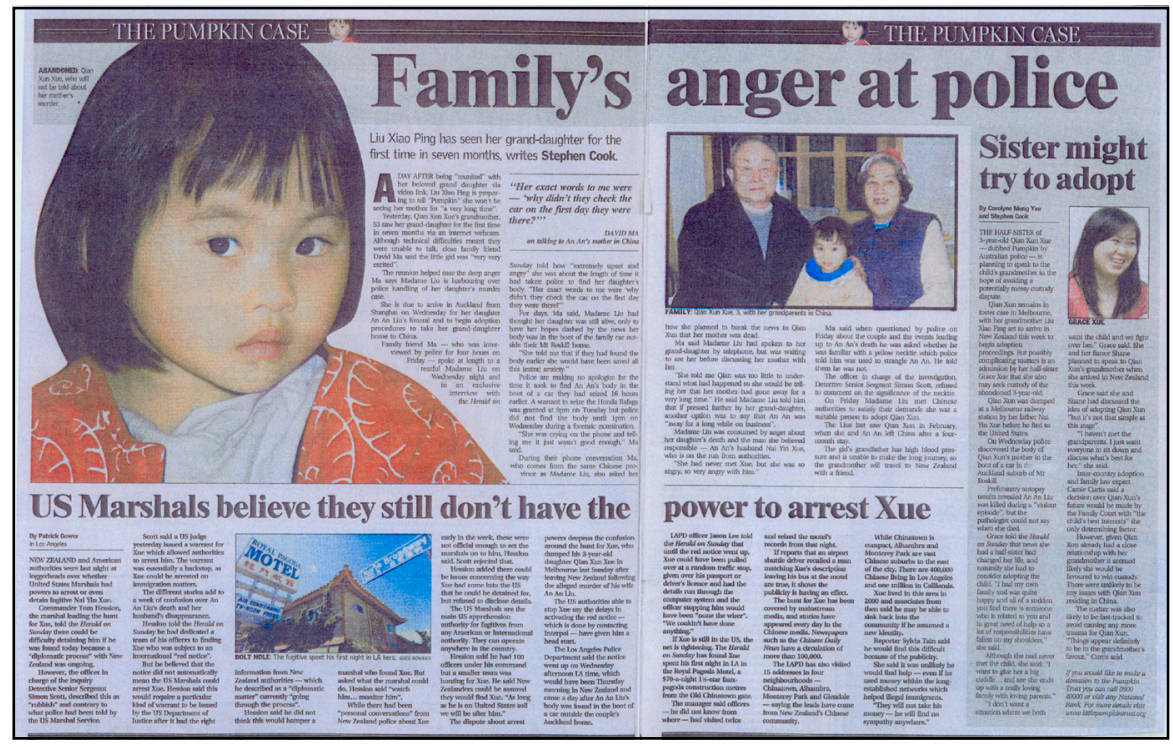

Figure 1: 'The Pumpkin case': Family's anger at police, Herald on Sunday, 23 September 2007.

\section{Discussion}

From these findings it can be seen that there are challenges for representation of Chinese victims of crimes and Chinese ethnic community representation in the news media. In both cases, there is a tendency for the victim's actual identity to be lost in the drama that surrounds the case. Throughout the unfolding of the case, Wan Biao is named but there is little else about his life or other's experience of him revealed. This results in less profile than is normally given to innocent victims of crime and the lack emotion about his death is a key omission. In crime representation, there is often an 
opportunity for the family to issue a public statement or express themselves in the news media (McGregor, 2002). In this story, the sole representation of Wan Biao is the limited response of a family spokesperson and there is little opportunity to empathise with the loss of the Biao family. The outcome of the Wan Biao murder trial provides the public with a moral law enforcement and legal system representation that clearly defines a set of perpetrators or wrong-doers. Biao however, is not an innocent victim but is subsumed into the homogenous categorisation of 'Asian'.

McGregor (2002, p.83) suggests that crime news often acts as the 'moral conscience' for the audience but in this case the simple moral message has become confused because Biao is not clearly defined as a member of New Zealand society. It could be argued that Biao's citizenship or residency is irrelevant but responsible ethnic journalism should take into account the most frequent associations with specific ethnic groups or communities that their media serves. As we have argued from the outset, the process of Asianisation and Biao's uncertain status as an international student seemingly justifies the lack of sympathy or development of his character as an innocent young man and temporary member of Auckland's Chinese ethnic community. Effectively, the media representation becomes ambiguous, suggesting that Biao's association with his murderers renders him partially to blame for his own murder.

The news and current affairs media do not present a fully contextualised picture of the pressing social concerns raised in this case. Though the Biao family themselves cannot speak on behalf of their family's anguish, the news media are in a position to examine the implications of pastoral care of international students. The speed and complexity of a television newsroom do provide practical constraints against indepth reporting and perhaps left them with little time to incorporate social issues (McGregor, 2002). But again, this lack of investigation into primary social issues that concern international students could be perceived as another by-product of Asianisation. Biao's murder does not stand alone in time and pastoral care of international students is highly relevant. The constraints of a newsroom might impede a detailed examination of the stories, but this is the arena where current affairs programmes would once have provided the context, breadth and depth required. ${ }^{7}$ Past news media analysis has shown that international students are frequently represented by their institutions, but that this focus is primarily based on economic concerns rather than the social challenges of 
intercultural adaptation by the international students(Benson, 2006). Concerns over international student welfare and pastoral care by institutions in New Zealand has been examined in media debates in the past (McFedries, 2002) and there is a precedent to examine these issues in an ongoing debate. The authors argue that the lack of investigation into responsibility by educational institutions and international student experience and integration into New Zealand life suggests there is less interest in the broader social issues than in reinstating familiar themes such as corruption and crime.

An An Liu is similarly decentralised as her daughter Ian Xun Xue or Baby Pumpkin is continually cast in the public limelight. Liu's position is reinforced by the regular speculation about the character of her husband Nian Yin Xue. Unlike Biao however, An An Liu (alongside her daughter) is placed within a framework that suggests she is 'good' and Nian Yin Xue is seen as 'bad' or at fault (McGregor, 2002). This portrays an innocence that is afforded both mother and daughter, playing into typical conservative gender stereotypes in news media (van Zoonen, 1991). This reinforcement of the basic binary concept of good and evil conveys a sense of balance to the case, leaving the audience to feel that justice has been served. However, this simplistic rendering does not to explore the complexities that might have led to the murder. The conservative treatment of this case implies that the situation is relatively simple and that the news media has been objective or balanced. However, the continual focus on Qian Xun Xue and the frequent use of her media nickname 'Baby Pumpkin' obscures the main issues and showed the media using a tabloid approach. This highly charged emotionality, Wyatt and Badger (1993) suggest, alters the function of a news item from information to vicarious experience for the audience. The actual 'personalities' or unknown facts of the case, both An An Liu and Qian Xun Xue, are lost in the confusion, allowing the audience to participate vicariously in the familiar emotional themes of drama and intrigue.

Although based in New Zealand, international components are also integral to the story adding elements of world news. It spanned four countriesNew Zealand, Australia, China and eventually the USA. Law enforcement agencies in three countries were represented alongside a broad cross-section of experts in New Zealand. Further characters in this case were interpreters, translators and media professionals. Neighbours in New Zealand and ethnic Chinese groups in both New Zealand and Australia completed this 
assortment. One of the main problems with the tabloid approach in intercultural communication between majority audiences and the Chinese community is that there is a limited amount of time used to convey complex information (Scollon \& Scollon, 2001). The narrative approach of the news media representation (Wyatt \& Badger, 2003) meant that the elements of the stories were presented in the same order that they were 'discovered', resulting in repetitious meanings on populist stereotypes such as ‘Baby Pumpkin' or Xue the martial artist and his 'Samurai' sword (Comrie, 1996). A more objective stance may have provided less sensational details and more analysis into the various elements of the unfolding story. It could be argued that these cases are examples of 'inferential' racism (Hall, 1990, as cited in Allan, 2004, p.13) where naturalised representations of:

...racist premises or propositions are in being inscribed in the media coverage as a set of unquestioned assumptions. These representations enable racist statements to be formulated without ever bringing into awareness the racist predicates on which the statement are grounded.

Another key concern of this descriptive approach is that the news media provides heavily subjective coverage because the main issues cannot be identified objectively (Wyatt \& Badger, 1993). Shallow coverage and lack of exploration into social issues was evident in both cases. At first glance the An An Liu case received copious coverage. But with closer examination and when the elements are pulled apart it is the lightweight details that are covered rather than the complexities or serious political and social issues raised by these cases. This is particularly evident with the continued reference to Nai Nai Yin Xue's martial arts. Commercial current affairs are not known for explaining complex issues but the problem is that TVNZ's Close Up did not present the stories in a substantially more detailed or layered manner than TV3. It could be argued that the heavily commercialised broadcasting environment provides no alternative to this approach.

Traditionally current affairs programmes were the genre that could explore issues and provide context with a range of expert views (Holland, 2005). The An An Liu case, offered a huge range of experts but in the current affairs coverage their input was restricted to banal and often narrowly focused discussions that failed to address the broader issues. Two members of parliament could have provided interpretation and debate of core issues, but their 
discussion was limited. This flawed approach to balance is reflective of what Hartley (1992, as cited in Allan, 2004) observes in relation to Aboriginal media coverage in Australia. He notes in his discussion of exclusion and inclusion, that Australian journalists routinely present Aborigines as constituent of 'they' rather than the 'us' of mainstream white journalism. In both cases Biao and Liu are presented in a limited binary representation where the balancing perspective reflects a majority non-Asian position.

There is little opportunity in these cases to question the limited media representation of the ethnic Chinese community in New Zealand. Qian Xun Xue is continually represented as 'small' or 'cute' and her father Nian Xin Xue is portrayed as a martial arts villain. While there is no doubt as to the innocence of Qian Xun Xue and the potential guilt of Nian Xue, there is a limited framework of reference. Mok (2007), a contemporary Asian social commentator and Public Address contributor suggests that a lot of the information on Nian Xin Xue is actually irrelevant:

I'm betting, along with the rest of the Roskill Chinese, that there are sadder things to uncover about Mr Xue and his wife than the fact that he teaches [tai chi], and despite being a mainlander, dresses like a daggy old Southeast Asian Chinese guy (\#3067, para 5).

A proportion of the so-called evidence from various neighbours and members of the community may actually be incorrect and based on stereotypical ignorance of the ethnic Chinese community and based on dress and manner rather than actual character. The selection of this information serves to obscure the identity of the accused Nai Xin Xue and Qian Xun Xue as well as An An Liu and frame them in a melange of so-called Asian characteristics. In this case, personalities are subverted into a natural stereotypical association and are similar to the treatment of Aboriginals in the Australian media (Hartley, 1992 as cited in Allan, 2004). The primary effect of this process is to place the Chinese ethnic minority or 'they' outside of the majority audience construct of 'us. However a secondary effect is to present a framework that obscures the case, which is the question of his guilt in the murder of An An Liu and the abandonment of Qian Xun Xue.

News media in New Zealand has the dual role of watchdog and to keep the New Zealand public informed of key issues and events (McGregor $\&$ Comrie, 2002). One of the largest omissions in these news and current 
affairs programmes is the lack of cultural understanding and contextualisation. Several brief interviews with Chinese officials and sensationalised additions by Chinese neighbours do not adequately provide contextualisation or cultural understanding. The coverage of each case leads to some interesting conclusions about TVNZ and TV3's ability to cover complex culturally different cases. The Wan Biao case is sterile in comparison to the Pumpkin case. It would seem that the media representation was unable to fit his death into established populist discourse about the loss of a promising young man and other tropes. Current affairs shows in particular, represent these cases simplistically and appear to serve to promote more racist views of Asians with crime, with Campbell even suggesting that - in everyday New Zealand, Asians and crime are synonymous.

These cases extend previous research into news and current affairs into a new area, examining the treatment of an ethnic minority group. The findings suggest that when the story falls into the ratings friendly area of a small cute child, albeit in a rather extraordinary story, that the media present this to the detriment of other facts. However, the treatment normally extended to alleged criminals is not followed and both channels display a cavalier approach to the question of guilt. Each channel is comfortable associating Nai Yin Xue's martial arts training with bullying. The interview of daughter Grace focuses on her emotional state and suggests that she is unhappy with her father. This compounds Nai Yin Xue's guilt because that too is caused by him. Complex dynamics are touched upon with the suggestion that the Asian community is unhappy with Grace. However, that story is not followed up. Overall, the treatment of these stories is consistent with Comrie's (1996) qualitative findings into the news which showed a growth in emotional, tabloid language in stories and headlines after deregulation.

Comrie's study into the news demonstrated a shift of function in news items from information to vicarious experience. Her study demonstrated a growing emphasis on the emotional aspects of these stories and an increasing exploitation of the dramatic potential. She suggested that news representation had altered to centre on the personal and emotional response of victims of crime. This study of Pumpkin follows this finding as the stories largely focus on emotional responses to the little girl. From 1987 Comrie noted that news coverage was shifting to coverage on the emotional, suffering and human interest stories. By 1989, the drama in the news had increased to the point 
where the audience were invited to be spectators and to share in the details of the distress of the victims (she notes too that this was a trend that also moved into newspapers see (McGregor and Comrie, 1995). There was an increase too in arrivals at court and pieces to camera and an emotional heightening of language (Comrie, 1996).

Wyatt and Badger's typology describes a heightening of the 'vicarious involvement of the viewer'. ${ }^{8}$ It suggests a move from description to the narrative genre and towards greater subjectivity. With this comes a tendency to 'direct the response of the viewer (often along a pre-set populist path)' (Comrie, 1996, p. 324). This Comrie suggests goes against some fundamental tenets of traditional journalism. This is the case in these examples where journalists seem comfortable making subjective comments about the victim, An An Liu and her personal life, the bad character of her Nai Yin Xue, the money he owed and the Asian crime wave. The primary purpose of narration, then, is involvement of the audience to engage and interrogate the event vicariously (Wyatt \& Badger, 1993).

More importantly, how these initial stories are framed sets up discourse where the focus is limited through narrow parameters rather than a fuller discussion of events. From a broader perspective this is often a characteristic of the media. For example Hall, Richter, Jefferson, Clark and Roberts (1999, p. 254) say of the media's ability to establish the initial interpretation of a topic:

The important point about the structured relationship between the media and the primary institutional definers is that it permits the institutional definers to establish the initial definition or primary interpretation of the topic in question. The interpretation then 'commands the field' in all subsequent treatment and sets the terms of reference within which all further coverage or debate takes place.

The media frames the stories through the filter of crime stories, which, when combined with news values and framing, means that only a very small portion of the background is presented. The discourse of the New Zealand news media consistently frames Asian stories within the established themes of immigration debates and centre around the role of Asians as outsiders irrespective of their status as residents or citizens (Spoonley \& Trlin, 2003). Wan Biao and An An Liu are victims of violent crimes, yet the focus on 
Asians as criminals takes predominance, reinstating it within the rising numbers of unpredictable and 'potentially dangerous' Asian immigrants.

\section{Conclusion}

The examination of these two stories raises many questions about New Zealand news and current affairs programmes' ability to deal with complex stories and deliver a thorough and fair representation of ethnically diverse groups. Previous research into the news suggested that a commercially driven broadcasting environment creates a drive for ratings with simplistic news treatments. The combination of news values, framing and a commercialised ratings-driven media then create problematic areas for Asian representation. The findings suggest that both news and current affairs should be spending more resources on understanding the Asian community and its diversity. A simplistic approach to any complex story is going to leave the audience short changed. These examples are reflective of an out of date vision of New Zealand demographics that does not represent a diverse audience.

Additionally, this is symptomatic of a broadcasting environment that does not easily handle complex stories or issues in the current affairs genre. Previous observations on the effects of increased entertainment values in the media have suggested that these lead to sensationalist forms of news coverage which can encourage white hostility toward minority groups such as African Americans (Entmen, 1997, as cited in Allan, 2004). The New Zealand of the present and future is far more diverse than the clumsy handling of these stories would suggest. Training of future journalists and media practitioners must incorporate a diverse vision of New Zealanders and keep pace with the changing needs of New Zealand society. Inferential racism is inherent throughout the media structures, and this suggests a need for increased ethnic diversity and in particular Asian ethnic groups as researchers and journalists. By incorporating and expanding the representation of minority ethnic media practitioners the implicit assumptions of identity and the location of 'we' can be expanded to include the Asian 'they'. Finally, this solution provides a practical approach to the difficulties of access to Asian communities.

These cases may present some unique difficulties for media coverage, yet changes need to be made in the manner that Asian as well as ethnic Chinese social groups are represented in the media. It is no longer adequate to represent victims from an ethnic minority group within news media discourses so 
that, by virtue of their ethnicity, appearance or colour of their skin, that they themselves are at fault. The close relationship between victim and perpetrator in the Biao case tended to conflate them into one group. This is compounded in the Liu case where more focus is placed on the innocence of Qian Xun Xue and the sensational commentary on Nai Yin Xue than on Liu as a victim. The reporting of these two cases suggests that these close associations, generalisations or stereotyping inherent in Asianisation are inevitable in a non-Chinese or Asian newsroom environment. The obscured reporting and general confusion of shallow Asianised stereotypes suggests that TV1 and TV3 are unaware of the changing needs of the New Zealand population and their audiences. Contemporary media coverage must strive to present Asians outside of polarised immigration debates and to allow these ethnic groups to take their full place in New Zealand society as citizens, residents and an established presence in a more multicultural New Zealand.

\section{Notes}

1. In this case, journalists made reports from the house about the missing woman who had been hidden in the car. Approximately two days afterwards, the police found the abandoned girl in the Melbourne train station.

2. Comrie (1996) for example found the treatment of crime stories altered to become more emotionally heightened with greater emphasis on the victims of crime and a generally more emotional treatment of the subject matter.

3. Agenda was screened on Saturday mornings at $8 \mathrm{am}$, a time slot unlikely to generate ratings. In 2008, Agenda has been screened on Sunday mornings.

4. Statistics New Zealand use a broad category "Asian groups" which includes ethnic groups from India and Pakistan as well as the more familiar East and South East Asian states such as ethnic groups from China, Japan and Malaysia for example.

5. The tai chi sword, called the tao (also spelled dao, meaning 'knife' or broadsword), the chien (also spelled jien, meaning straight sword) and the chang (spear, or sometimes the staff).

6. Though the reporters suggest that this documentary is startling the actual documentary is a mundane account of the life of a travelling tai chi teacher. The motives or reasons behind Nai Yin Xue's actions in the current situation are not explained and the documentary says little.

7. Holland (2001) discusses the key tenets of the first current affairs programmes and how these differ from news programmes.

8. Description, according to Wyatt and Badger (1993) suggest, in journalism is central to: straight news coverage, particularly when it serves the purpose not only of 'picturing' a scene or setting but of conveying other information about a news occurrence. Description is usually structured in accordance to the importance of the 
elements. This is Different to the narrative approach that prioritisesthe sequence of events.

\section{References}

Abandoned girl came from NZ (2007, September 17). On TVNZ News Bulletin [News Broadcast]. Auckland, New Zealand: Television New Zealand. Retrieved from TVNZ on Demand website on 1 April 2008, from: tvnz.co.nz/content/?q=archive\&style $=$ tvnz

Allan (2004). News culture. (Second Ed.). Berkshire, England: Open University Press.

Asian crime - scourge or media beat up (2006 April 28) On Campbell Live [Current Affairs Broadcast]. Retrieved from the TV3 website on 8 April 2008, from: www. tv3.co.nz/Video/AsianCrimeScourgeorMediaBeatup/tabid/367/articleID/7117/ cat/100/Default.aspx

Atkinson, J. (1994). The state, the media, and thin democracy'. In A. Sharp (Ed.), Leap into the dark. Auckland: Auckland University Press.

Atkinson, J. (2006). Performance journalism and the public interest. Paper presented to the In the public Interest Conference, University of Canterbury, Christchurch, 25 - 26 August, 2006.

America's Most Wanted, (n.d.). Fugitives. Retrieved on 1 April 2007, from: www.amw.com/fugitives/brief.cfm?id=49159

Baker, S. J. (2007). The death of a genre? Television current affairs programmes on New Zealand public television. Paper presented to the ANZCA 2007 Annual Conference, La Trobe University, Melbourne, 5-7 July 2007.

Bennett, N. (1998). Asian students in New Zealand. Wellington, New Zealand: Institute of Policy Studies.

Bennett, M. J. (2005). Intercultural communication: A current perspective. In C. P. Harvey \& M. J. Allard (Eds.), Understanding and managing diversity. Readings, cases and exercises (pp. 52-80). Upper Saddle River, NJ: Pearson/ Prentice Hall.

Benson, S. J. (2003). Students not immigrants: A sociological analysis of how key New Zealand dailies conflate East Asian international students with 'Asian' immigrants' Paper presented at the Knowledge, Capitalism, Critique, Auckland University of Technology, Auckland, New Zealand. September 9-11. http://saanz.science.org. nz/Quality.htm

Benson, S. J. (2004). Exploring print media links of gambling and corruption with the Asian 'other'. Paper presented at Gambling and Problem Gambling in New Zealand: Taking Stock and Moving Forward on Policy, Practice and Research, Auckland University of Technology, Auckland, New Zealand. www.ijma-journal.com/issues/conferences/abstracts/2

Benson, S. J. (2006). Commodification of Asian international students in radio media discourse. New Zealand Asia Studies Journal, 8(1): pp. 94-107. 
Body in suitcase accused appear. (2006, September 5). On TVNZ News Bulletin [News Broadcast]. Auckland, New Zealand: Television New Zealand. Retrieved from TVNZ on Demand website on 1 April 2008, from: tvnz.co.nz/content $/ ? \mathrm{q}=$ archive \& style $=$ tvnz

'Body in a suitcase' murderers sentenced to a life in prison (2007, December 6). On TV3 News Bulletin [News Broadcast]. Retrieved from TV3 website on 1 April 2008, from: www.tv3.co.nz/VideoBrowseAll/NationalVideo/tabid/309/ articleID/40930/cat/100/Default.aspx\#video

Cocker, A. (2006). The Television New Zealand charter: Rethinking deregulated broadcasting. Paper presented to the ANZCA conference, University of Adelaide, Adelaide, July 2006.

Cook, D. (2000), Deregulation and broadcast news content: ONN 1984-96, unpublished $\mathrm{PhD}$ thesis, University of Auckland.

Comrie, M. (1996). The commercial imperative in broadcasting news: TVNZ from 1985 to 1990: unpublished PhD thesis, Massey University.

Disturbing revelation in suitcase trial. (2007, September 14). On TVNZ News Bulletin. Auckland, New Zealand: Television New Zealand. Retrieved from TVNZ on Demand website on 1 April 2008, from: tvnz.co.nz/content/?q=archive\&style=tvnz.

Grant, D. (2002). The nature of gambling in New Zealand: A brief history. In B. Curtis (Ed.), Gambling in New Zealand (pp. 75-90). Palmerston North, New Zealand: Dunmore Press Ltd.

Edwards, B. (2002.) The cootchie coo news revisited. In M. Comrie and J McGregor (Eds.)., What's news? (pp. 16 - 32). Palmerston North: Dunmore Press.

Family's anger at police. (2007, September 23,). Herald on Sunday, pp. 10-11.

Hall, S., Crichter, C., Jefferson, T., Clark J. \& Roberts B. (1999). Policing the crisis. In H. Tumber (Ed.). News: A reader.(pp. 249-266). Oxford, UK: Oxford University Press.

Holland, P (2001). Authority and authenticity: Redefining television current affairs. In M. Bromley (Ed.)., No news is bad news radio, television and the public (pp. 80-95). London: Longman.

Holland, P. (2006). The angry buzz. London: I.B Taurus.

Interview with the officer in charge of the abandoned toddler case (2007, September 17). On TV3 News Bulletin [News Broadcast] Retrieved from TV3 website on 1 April 2008, from: www.tv3.co.nz/VideoBrowseAll/NationalVideo/ tabid/309/ articleID/34915/Default.aspx\#video

Johnson-Cartee, K. S. (2005). News narrative and news framing: Constructing political reality. Lanham, MD: Rowman and Littlefield Publishers Inc.

Kelsey, J. (1995). The New Zealand experiment: A world model for structural adjustment? Wellington: Auckland University Press with Bridget Williams Books.

Mathews, G. (2000). Global culture/individual identity: Searching for home in the cultural supermarket. London \& New York: Routledge.

McGregor, J. (2002). Crime news: The cutting edge. In J. McGregor \& M. Comrie (Eds.), Whats news? Reclaiming journalism in New Zealand (pp. 81-95). Palmerston North, New Zealand: Dunmore Press. 
McFedries, T. H. (2002). Asian fee-paying secondary school students in New Zealand. Paper presented at the Annual international educational conference, Wellington, New Zealand. www.nzeil.co.nz/documents/Terry_McFedries.pdf

Mok, T. M. (2007). Yellow peril. Retrieved on 1 April 2008, from: Public Address website: www.publicaddress.net/default,3067.sm\#post3067

More testimony in suitcase trial. (2007, September 4). On TVNZ News Bulletin [News Broadcast]. Auckland, New Zealand: Television New Zealand. Retrieved from TVNZ on Demand website on 1 April 2008, from: tvnz.co.nz/content/?q=archive\&style=tvnz.

Munshi, D. (1998). Media, politics and the Asianisation of a polarised immigration debate. Australian Journal of Communication, 25(1): pp. 97-110.

Pumpkin. (2007, September 18).On Close-Up [Current Affairs Broadcast]. Auckland, New Zealand: Television New Zealand. Retrieved from TVNZ on Demand website on 1 April 2008, from tvnz.co.nz/content/?q=archive\&style=tvnz

Pumpkin's father has another daughter who disappeared (2007, September18) On TV3 News Bulletin [News Broadcast]. Retrieved from TV3 website on 8 April 2008, from www.tv3.co.nz/VideoBrowseAll/NationalVideo/tabid/309/ articleID/34982/Default.aspx\#video

Police: Body found at Xue house (2007, 19 September) On TV3 News Bulletin [News Broadcast]. Retrieved from Tv3 website on 8 April 2008, from: www.tv3.co.nz/ VideoBrowseAll/NationalVideo/tabid/309/articleID/35053/Default.aspx\#video Saunders, B. (2004, March 13). The Lost Language of debate. The Listener, pp. 32-33.

Scollon, R., \& Scollon, S. W. (2001). Intercultural communication. Oxford, UK: Blackwell Publishers.

Spoonley, P., \& Trlin, A. D. (2003). Immigration, immigrants and the media:Making sense of multicultural New Zealand. Palmerston North, New Zealand: Massey University.

Statistics New Zealand. (2006). Quick stats about New Zealand population and dwellings [Online Version]. From the official web site of Statistics New Zealand http:// www.stats.govt.nz/NR/rdonlyres/CCA37BF2-2E49-44D4-82AB-35538608DEF D/0/2006censusquickstatsaboutnzspopanddwellings1.pdf

Tuesday. (2007, September 18). Tuesday. On Close-Up. [Current Affairs Broadcast]. TVNZ on demand. Television New Zealand. Retrieved from TVNZ on Demand website on 1 April 2008, from: tvnz.co.nz/content/?q=archive\&style=tvnz

Thompson, P. A. (2004). Unto God or unto Caesar? Television after the TVNZ charter.

Communication Journal of New Zealand: He Kohinga Korero, 5 (2): pp. 59-90.

van Zoonen, L. (1991). Feminist Perspectives on the media. In J. Curran \& M Guretvich (Eds.)., Mass media and society. (pp. 33-54). New York, USA: Edward Arnold Press.

Wyatt,R.O., \& Badger, D.P.(1993). A new typology for journalism and mass communication writing. Journalism Educator, 48 (1): pp. 3-11.

Zee, W. (2002). Wu style tai chi chuan. Ancient Chinese way to health. Berkeley, $\mathrm{Cal}$ : North Atlantic Books. 
Sarah Baker is in AUT University's School of Communications and researches the New Zealand television industry, focusing on current affairs programmes, deregulation and the political economy of the media. Jeanie Benson is in AUT University's School of Communications and researches East and South East Asian international student experiences of New Zealanders. An earlier version of this article was delivered at the 17th Asian Media Information and Communication Centre (AMIC) conference in Manila, Philippines, on 14-17 July 2008.

Sarah.Baker@aut.ac.nz

Jeanie.Benson@aut.ac.nz

\section{Journalism under fire:

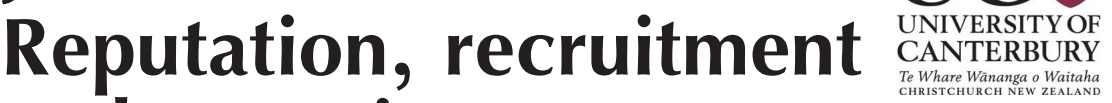 and retention}

Annual conference of the Journalism Education Association of New Zealand

\section{University of Canterbury, Christchurch, NZ}

8-9 December, 2008

Organised by the University of Canterbury Mass Communication and Journalism Programmes in association with the Christchurch Polytechnic and Institute of Technology, Aoraki Polytechnic and the Southland Institute of Technology.

Journalism in Aotearoa New Zealand has come under sustained pressure in the past few years. From rationalisation at APN and Fairfax to the leaching of audiences by emerging digital media to a longer-term loss of reputation, the news has not been good. The central theme of this year's JEANZ conference is how the industry, the profession, journalism trainers and observers are responding. Proposals for papers, panels and workshops that contribute to the debate are warmly invited, including presentations on teaching aspects of the journalism curriculum.

Please send abstracts to jim.tully@canterbury.ac.nz. Deadline for abstracts: 31 October. These will be blind peer reviewed prior to acceptance. Full refereeing of papers is available for participants whose funding is dependent on this. 